\title{
Grand challenges in cellular biochemistry: the "next-gen" biochemistry
}

\author{
Cecilia Giulivi ${ }^{1,2 *}$ \\ 1 Department of Molecular Biosciences, University of California, Davis, Davis, CA, USA \\ ${ }^{2}$ Medical Investigations of Neurodevelopmental Disorders Institute, University of California, Davis, Davis, CA, USA \\ *Correspondence: cgiulivi@ucdavis.edu
}

Edited and reviewed by:

Venkaiah Betapudi, Cleveland Clinic Foundation, USA

Keywords: biochemistry, history, RNA, enzymes, instrumentation, advances, discoveries, one-health

It is said that Biochemistry is a young scientific discipline, making its "formal" debut toward the end of the 1900th century (Manchester, 2000), with seminal works by Buchner (1897, Jaenicke, 2007), (Pasteur and Berthelot, 1906), Hill (1898), Embden and Glaessner (1901), Meyerhof (1911), Parnas (1911), Harden (1911), and, of course, Michaelis and Menten (Johnson, 2013; Michaelis and Menten, 2013; Deichmann et al., 2014). These early and important contributions marked the road for future work in the fields of (a) chemical and biochemical structures and associated functions by Sanger (1945), Perutz (1942), Franklin (1950), Watson and Crick (1953), Pauling et al. (1949, 1951), Pauling and Corey (1951), Zuckerkandl and Pauling (1962), Kornberg (1974, 1977), Boyer (1997), Walker et al. (1982), Abrahams et al. (1994); (b) metabolic pathways and regulation by Ochoa and Valdecasas (1929), Krebs and Johnson (1937), Novelli and Lipmann (1947), Fischer et al. (1959), Cori and Cori (1923, 1925), Houssay (1945, 1948), Lehninger (1942, 1945), Caputto et al. (1949), Cardini et al. (1950), Mitchell (1961), Benson and Calvin (1947), Hershko et al. (1980), Hershko and Ciechanover (1992), and (c) contributing to innovative techniques or approaches dedicated to advance basic knowledge (and making our lives easier) with Smith (1982), Winter et al. (1982), Mullis et al. (1986) (ante and post-PCR era) and Shimomura (1979), Chalfie et al. (1994), Heim et al. (1994) (ante and post-green fluorescent protein), Yalow et al. (1964), and Williams et al. (1977), Springer et al. (1979); (d) signaling molecules and signal transduction by LeviMontalcini and Amprino (1947), Cohen et al. (1954), Sibley et al. (1986), Benovic et al. (1987), Frielle et al. (1987), Fargin et al. (1988).

Back in 1896, Buchner's preparation of a "juice" from yeast (Buchner, 1897) is often regarded as the birth of modern biochemistry. However, I tend to digress with this strict view of biochemistry, reasoning that we (as a species) were taking advantage of biochemical principles without having a deep understanding of the underlying molecular processes. For instance, consider Buchner's "juice" or actually wine making. This method, that has at its core the fermentation process one of the key pathways in biochemistry, dating back to around $6000 \mathrm{BC}$ (Chambers and Pretorius, 2010). Refer to the complicated production of fish sauces considered among the most common flavor-enhancing condiments produced and distributed across ancient Roman Empire (Lowe, 2009). Another example comes from the mixture of organic preservatives (i.e., biochemical) used for ancient Egyptian mummification (Buckley and Evershed, 2001). Or think about the effects of diet on health as recognized by Hippocrates (460-377 BC; Caramia, 2006), the arab physician Ibn al-Nafis (Al-Nafis, 13th century) and Leonardo da Vinci (1452-1519; Caramia, 2006) as well as the experimentation with animals and structure-function of human body set by the Medieval Islamic era as early as the 9th century (AbdelHalim, 2011). This early biochemistry was empirical, done in settings other than laboratories, serving immediate needs, and some passed onto next generations by oral traditions. Then we would reason, are these contributions valuable to the genesis of biochemistry? Should they be dismissed because the microorganisms were not genotyped, the reactions were done in dolia instead of microplates? Then, if we accept these very early facts (and why not experiments?) as part of the genesis of this field, we will need to accept that biochemistry is a long, long (ancient?) journey that has accompanied us since the dawn of civilization.

The general field of Biochemistry has grown since then to the point that it has been expanded to various more specific areas of research. For example, Cellular Biochemistry is at the crossroads of Chemistry (Organic, Physical, Analytical, Inorganic, Biological) and Biology (Chemical, Molecular) including studies on biomolecular structures and the mechanism of biochemical reactions, but also on the biological purposes of biochemical phenomena, i.e., metabolic pathways and their control, physiological significance and clinical relevance of topics presented. The regulation includes protein and gene expression analyses as well as protein post-translational modifications, epigenetic controls, metabolite-control systems, and gene-environment interactions as well as cell-cell interactions. This field covers areas from fundamental biochemical principles (e.g., enzymology, macromolecule structures) in cell-free systems to pathways, their regulation, and integration in physiology, and how their disturbance could lead to a number of diseases.

While tremendous progress has been achieved, here are some of the aspects that 
we think needs additional attention in the next upcoming years.

\section{ON PROTEINS: HIDING BEHIND A POST-TRANSLATIONAL MODIFICATION}

How many new post-translational modifications have been found after the relevant discoveries on protein phosphorylation and their impact on signal transduction pathways (Fischer, 2013)? Among them, ubiquitination (Schmidt and Finley, 2014; Schreiber and Peter, 2014), methylation (Afjehi-Sadat and Garcia, 2013; Clarke, 2013), sumoylation (Yang and Chiang, 2013), acylation (Storck et al., 2013; Running, 2014), glycation (Nedic et al., 2013; Sousa Silva et al., 2013), nitrosylation (Gould et al., 2013; Michelet et al., 2013), glutathionylation (Allen and Mieyal, 2012; Zaffagnini et al., 2012), tyrosine O-sulfation (Kim et al., 2005), dityrosine crosslinks (Giulivi et al., 2003), ADP-ribosylation (Dani et al., 2013), and lysine acetylation (Bernal et al., 2014; Cain et al., 2014; Dos Santos-Pinto et al., 2014; Wang et al., 2014). It is clear that in some of these examples the modifications accompanied a biochemical or metabolic process (e.g., fasting Yang et al., 2011). But, so far limited cases have demonstrated that a single protein modification on a given target modulated a protein activity, and as a result, a pathway (e.g., Nie et al., 2009), modified the protein subcellular location (e.g., Moeller and Fenton, 2012), or the fate (e.g., Spasser and Brik, 2012). Then, how many of these modifications normally found in a cell are truly relevant to a specific biological process (Catherman et al., 2014; Dos SantosPinto et al., 2014; Vaudel et al., 2014)? Are they silent by-standers, surrogate markers (Pimentel et al., 2012; Perluigi et al., 2014)? Is there a hierarchical order or a crosstalk among several protein modifications within a single protein? What are the purposes of these modifications (Moore and Gozani, 2014)? What if the modified protein is not a rate-limiting step of a given pathway and/or has a high turnover? In what cellular compartments or organs are these modifications found? To gain a better understanding of protein modifications, which enhance and extend the diversity of proteins beyond that encoded by DNA and the transcriptome, we need to clarify these questions to truly understand the meaning of regulation of pathways in biochemistry and their relevance in disease.

\section{ON RNA AND ITS LANDSCAPE: THE MORE THE MERRIER}

In the midst of enzyme isoforms, metabolite controls, post-translational modifications, compartmentalization, gene transcription, protein-protein interactions, microRNAs (miRNAs), or small non-coding RNAs have emerged as new post-transcriptional regulators of gene expression (Feng et al., 2014). To date, a myriad of diverse cellular events [cognition, synapsis, cell fate, plasticity, cancer (Asrih and Steffens, 2013; Clifford et al., 2013; Di Leva and Croce, 2013; O’Carroll and Schaefer, 2013; Feng et al., 2014)] have been claimed to be regulated by miRNA. As indicated above for novel protein posttranslational modifications, we are just starting to unveil the cause-effect for a limited number of miRNAs. Thus, more research is needed to address the links between miRNA expression and miRNAtargeted genes, the association between miRNAs and messenger RNAs, how this new regulation works in association (or not) with others already present in the cell, and what role miRNAs might have played in phenotypic evolution (Akbari Moqadam et al., 2013; Luo et al., 2013; Marco et al., 2013). To complicate the story further, next generation sequencing technologies targeting the miRNA transcriptome revealed the occurrence of RNA fragments different from miRNAs. A growing evidence suggests that RNA fragments derived from small nucleolar RNA (snoRNA) and transfer RNA (tRNA) are neither RNA turnover artifacts nor random degradation products but rather stable species, which may have functional activity in the normal as well as in cancer cells (Falaleeva and Stamm, 2013; Lui and Lowe, 2013; Martens-Uzunova et al., 2013). But the story does not end here. Long non-coding RNAs (lncRNA) have been described to act as decoys of RNAbinding proteins or microRNAs and can compete for microRNA-mediated inhibition leading to increased expression of the mRNA (Louro et al., 2009; Whitehead et al., 2009; Yoon et al., 2013; Diederichs, 2014; Fatica and Bozzoni, 2014; Johnsson et al., 2014; Nakagawa and Kageyama, 2014). Future studies would need to decipher how these different messages (including circular RNA) are read by the cell, their role in regulating pathways or cellular processes, and their link to other regulatory systems (Tay et al., 2014).

\section{ON INTER-CELLULAR COMMUNICATION: CELL-DERIVED MEMBRANE VESICLES AS THE NEW MOLECULAR MERCURY}

The relatively recent discoveries on the occurrence of cell-derived membrane vesicles (CVMs) add another layer of complexity to the field of cell-cell communication. CMVs have a biological cargo constituted by proteins, RNA or DNA, with the potential to change the phenotype of the receiving cell (Quesenberry and Aliotta, 2010; Rak, 2010; Lee et al., 2011; Sadallah et al., 2011). These vesicles are classified into exosomes, ectosomes, microvesicles, microparticles, apoptotic bodies, and are originated from different subcellular compartments. The molecular mechanisms regulating their formation, release and degradation are not fully understood; however, several studies highlight their role in tumor growth, microRNA delivery, atherosclerosis, preeclampsia, as well as their potential use as drug delivery (Aatonen et al., 2012; Biancone et al., 2012; Lee et al., 2012; Redman et al., 2012; Soleti and Martinez, 2012; van Dommelen et al., 2012; Vickers and Remaley, 2012; Camussi et al., 2013; Choi et al., 2013; Gonda et al., 2013; Inal et al., 2013; Martins et al., 2013; Principe et al., 2013; Loyer et al., 2014).

\section{ON INTERDISCIPLINARY APPROACHES: ARE WE LISTENING- MORE THAN TALKING - TO EACH OTHER?}

Theories have a transient nature; they last only until replaced by ones more consistent with the accumulated facts. To acquire "new information," a great variety of methods must be used and their optimization or discovery of new methods will be an important area of research in the coming years. Studying isolated organelles, intact cells, tissues or organs may be seen as unphysiological and thus, requiring a considerable extrapolation of these results to animals including humans. Although these interpretations must always be made with caution, studies in intact organisms 
have the advantage of observing processes as a whole with the clear disadvantage that few of these processes occurring within it are accessible to study. In other words, while a considerable fractionation of the scientific problem may lead to the identification of key components, the way in which they interact may not be as in the intact organism. In this regard, data obtained in vitro and/or with simpler models have been used in dynamic mathematical modeling to promote a comprehensive understanding of in vivo complex mechanisms (Tummler et al., 2014). In addition to the advance of more accurate mathematical models, effort needs to be devoted at the development of in vivo, non-invasive techniques and methods to bridge the gaps between in vitro and in vivo systems (Zheng et al., 2011; Nandakumar et al., 2012; Ramkumar et al., 2013). The use of novel, non-invasive imaging techniques to follow, for instance, parasitemia (Maclean et al., 2013) or muscle oxygenation (Hamaoka et al., 2011) as well as fine-regulated molecular approaches such as optogenetics (Doll and Broadie, 2014; Sidor and McClung, 2014) or even more sensitive mass spectrometry technologies will be leading the future of Cellular Biochemistry. It also means to develop models that accurately mimic complex chemical systems as pioneered by Karplus (1959, 1963), Warshel and Levitt (1976), Chothia et al. (1989) and Levitt and Warshel (1975). Evidently, interdisciplinary approaches (which means interacting with colleagues in other fields) are needed to develop more sensitive and specific probes (chemistry), instrumentation (analytical instrumentation, computer engineering, bioinformatics), validation of targets (biochemistry) and delivery (nanomaterials, pharmacology, medicinal chemistry) to be applicable to medicine.

The interdisciplinary approach has a strong influence on the transition into "personalized medicine" which essentially requires the integration of various molecular approaches (proteomics, metabolomics, genome sequencing, imaging, to name a few) with the idea of providing the most effective therapy, minimizing side effects, and shortening treatment periods (Nandy et al., 2014; Stenson et al., 2014). One of the next challenges will be to integrate these interdisciplinary approaches in the clinics and making them affordable to all patients (Johnson et al., 2012).

\section{ON THE ORGANISM OF CHOICE: WELCOME TO THE BATTLEGROUND}

Studies on simpler organisms such as worms, flies, yeast could be seen as somehow irrelevant to those in higher organisms, particularly with the wide use of murine models (Russell, 2013). However, if the question or problem resides within a highly conserved pathway across these species, the use of "relatively" simpler systems gives a unique opportunity to address a complex problem (Bednarova et al., 2013; Dassati et al., 2014). Studying these conserved or homologous processes across species and their modifications in front of environmental exposures will also integrate the field of gene-environment interactions (Napoli et al., 2013) and their impact on human disorders such as autism and obesity (Razquin et al., 2011; Schmidt et al., 2012; Galbete et al., 2013; Napoli et al., 2013; Lyall et al., 2014) as well as the evolutionary pressure to best suit the need (for example, Gnankine et al., 2013). In this context, an area that needs to be addressed is how we are re-defining our choices when selecting a biological study model to answer a particular question. For instance, the relevance of selecting a murine genetic background (even if inbred) that will not interfere with the issue of interest (e.g., Bourdi et al., 2011; Ulmasov et al., 2013), and still be reasonable breeders with relatively good health. Looking beyond the traditional murine models to uncover human-like diseases opens the door to collaborations between veterinarians and basic researchers (for example, Vernau et al., 2013) and explore new therapies (Patel et al., 2011; Nielsen et al., 2014), including the use of stem cells (Volk and Theoret, 2013) and "personalized medicine" (Palotie et al., 2013). Acrossspecies studies fall under the umbrella named "One Health" initiative, which since 1984 combines human, animal, and environmental components to addressing global health challenges (Bidaisee and Macpherson, 2014). To this end, we will need to look up from our laboratory bench and try to understand the basis of diseases within ecosystems, reaching out to global health (Gutierrez et al., 2012; Conrad et al., 2013; Miller and Olea-Popelka, 2013).

\section{CONCLUDING REMARKS}

Progress in science is made either from discovering new facts or from re-interpreting well-established ones. In line with this concept, we should provide a balanced account of controversial areas and consider that the presentation of different views is important to reinforce the point that theories or hypotheses must always be open to reinterpretation with the advancement of knowledge [e.g., the use of vitamin D on osteoporosis (Reid et al., 2014)]. Indications of doubt raised by published studies provide impetus for further research by students, researchers, and clinicians. As processes evolve once they exist, it is our goal to shape the vision of Cellular Biochemistry adapting and evolving to the fast pace of scientific discoveries, trying to make this area the most suitable bridge between molecular biochemistry and medicine, placing it at the heart of translational medicine.

\section{ACKNOWLEDGMENTS}

These advances, and those yet to come, are owed to our colleagues mentioned here and many, many others that have contributed to this field. We appreciate deeply their personal sacrifices and immense commitment to the advancement of science. To continue to move forward, as Dr. Kornberg indicated in his "Ten Commandments of Enzymology, amended" (Kornberg, 2003), we need to raise awareness and acknowledge the support of the National Institutes of Health, National Science Foundation as well as that of many wonderful Foundations that have provided the means to achieve these advancements and, hopefully, continue to accompany us on this exciting ride. This work has been partly supported by the National Institutes for Health (R01ES020392 and R01HD036071), NIEHS R01-ES011269, R01-ES015359 and R01-ES020392, and Simons Foundation (SFARI 271406).

\section{REFERENCES}

Aatonen, M., Gronholm, M., and Siljander, P. R. (2012). Platelet-derived microvesicles: multitalented participants in intercellular communication. 
Semin. Thromb. Hemost. 38, 102-113. doi: 10.1055/s-0031-1300956

Abdel-Halim, R. E. (2011). Experimental medicine 1000 years ago. Urol. Ann. 3, 55-61. doi: 10.4103/ 0974-7796.82168

Abrahams, J. P., Leslie, A. G., Lutter, R., and Walker, J. E. (1994). Structure at 2.8 A resolution of F1ATPase from bovine heart mitochondria. Nature 370, 621-628. doi: 10.1038/370621a0

Afjehi-Sadat, L., and Garcia, B. A. (2013). Comprehending dynamic protein methylation with mass spectrometry. Curr. Opin. Chem. Biol. 17, 12-19. doi: 10.1016/j.cbpa.2012.12.023

Akbari Moqadam, F., Pieters, R., and Den Boer, M. L. (2013). The hunting of targets: challenge in miRNA research. Leukemia 27, 16-23. doi: 10.1038/leu.2012.179

Allen, E. M., and Mieyal, J. J. (2012). Protein-thiol oxidation and cell death: regulatory role of glutaredoxins. Antioxid. Redox Signal. 17, 1748-1763. doi: 10.1089/ars.2012.4644

Al-Nafis, I. (13th century). Kitab al-Mukhtar min-alAgthi'ya.

Asrih, M., and Steffens, S. (2013). Emerging role of epigenetics and miRNA in diabetic cardiomyopathy. Cardiovasc. Pathol. 22, 117-125. doi: 10.1016/j.carpath.2012.07.004

Bednarova, A., Kodrik, D., and Krishnan, N. (2013). Unique roles of glucagon and glucagon-like peptides: parallels in understanding the functions of adipokinetic hormones in stress responses in insects. Comp. Biochem. Physiol. Part A Mol. Integr. Physiol. 164, 91-100. doi: 10.1016/j.cbpa. 2012.10.012

Benovic, J. L., Kuehn, H., Weyand, I., Codina, J., Caron, M. G., and Lefkowitz, R. J. (1987). Functional desensitization of the isolated $\beta$ adrenergic receptor by the $\beta$-adrenergic receptor kinase: potential role of an analog of the retinal protein arrestin $(48-\mathrm{kDa}$ protein). Proc. Natl. Acad. Sci. U.S.A. 84, 8879-8882. doi: 10.1073/pnas.84.24.8879

Benson, A., and Calvin, M. (1947). Dark reductions of photosynthesis. Science 105, 648-649. doi: 10.1126/science.105.2738.648

Bernal, V., Castano-Cerezo, S., Gallego-Jara, J., EcijaConesa, A., de Diego, T., Iborra, J. L., et al. (2014). Regulation of bacterial physiology by lysine acetylation of proteins. N. Biotechnol. doi: 10.1016/j.nbt.2014.03.002. [Epub ahead of print].

Biancone, L., Bruno, S., Deregibus, M. C., Tetta, C., and Camussi, G. (2012). Therapeutic potential of mesenchymal stem cell-derived microvesicles. Nephrol. Dial. Transplant. 27, 3037-3042. doi: $10.1093 / \mathrm{ndt} / \mathrm{gfs} 168$

Bidaisee, S., and Macpherson, C. N. (2014). Zoonoses and one health: a review of the literature. J. Parasitol. Res. 2014:874345. doi: 10.1155/2014/ 874345

Bourdi, M., Davies, J. S., and Pohl, L. R. (2011). Mispairing C57BL/6 substrains of genetically engineered mice and wild-type controls can lead to confounding results as it did in studies of JNK2 in acetaminophen and concanavalin a liver injury. Chem. Res. Toxicol. 24, 794-796. doi: $10.1021 / \mathrm{tx} 200143 \mathrm{x}$

Boyer, P. D. (1997). The ATP synthase - a splendid molecular machine. Annu. Rev. Biochem. 66, 717-749. doi: 10.1146/annurev.biochem.66.1.717
Buchner, E. (1897). Alkoholische gährung ohne hefezellen. Ber. Dt. Chem. Ges. 30, 117-124. doi: 10.1002/cber.18970300121

Buckley, S. A., and Evershed, R. P. (2001). Organic chemistry of embalming agents in Pharaonic and Graeco-Roman mummies. Nature 413, 837-841. doi: 10.1038/35101588

Cain, J. A., Solis, N., and Cordwell, S. J. (2014). Beyond gene expression: the impact of protein post-translational modifications in bacteria. J. Proteomics 97, 265-286. doi: 10.1016/j.jprot. 2013.08.012

Camussi, G., Deregibus, M. C., and Tetta, C. (2013). Tumor-derived microvesicles and the cancer microenvironment. Curr. Mol. Med. 13, 58-67. doi: 10.2174/156652413804486304

Caputto, R., Leloir, L. F., Trucco, R. E., Cardini, C. E., and Paladini, A. C. (1949). Enzymic transformation of galactose into glucose derivatives. J. Biol. Chem. 179, 497-498.

Caramia, G. (2006). [Virgin olive oil. From legend to scientific knowledge of the nutraceutical aspects]. Pediatr. Med. Chir. 28, 9-23.

Cardini, C. E., Paladini, A. C., Caputto, R., and Leloir, L. F. (1950). Uridine diphosphate glucose: the coenzyme of the galactose-glucose phosphate isomerization. Nature 165, 191-192. doi: 10.1038/165191a0

Catherman, A. D., Skinner, O. S., and Kelleher, N. L. (2014). Top down proteomics: facts and perspectives. Biochem. Biophys. Res. Commun. 445, 683-693. doi: 10.1016/j.bbrc.2014.02.041

Chalfie, M., Tu, Y., Euskirchen, G., Ward, W. W., and Prasher, D. C. (1994). Green fluorescent protein as a marker for gene expression. Science 263, 802-805. doi: 10.1126/science.8303295

Chambers, P. J., and Pretorius, I. S. (2010). Fermenting knowledge: the history of winemaking, science and yeast research. EMBO Rep. 11, 914-920. doi: 10.1038/embor.2010.179

Choi, D. S., Kim, D. K., Kim, Y. K., and Gho, Y. S. (2013). Proteomics, transcriptomics and lipidomics of exosomes and ectosomes. Proteomics 13, 1554-1571. doi: 10.1002/pmic.201 200329

Chothia, C., Lesk, A. M., Tramontano, A., Levitt, M., Smith-Gill, S. J., Air, G., et al. (1989). Conformations of immunoglobulin hypervariable regions. Nature 342, 877-883. doi: 10.1038/ $342877 \mathrm{a} 0$

Clarke, S. G. (2013). Protein methylation at the surface and buried deep: thinking outside the histone box. Trends Biochem. Sci. 38, 243-252. doi: 10.1016/j.tibs.2013.02.004

Clifford, R. L., Singer, C. A., and John, A. E. (2013). Epigenetics and miRNA emerge as key regulators of smooth muscle cell phenotype and function. Pulm. Pharmacol. Ther. 26, 75-85. doi: 10.1016/j.pupt.2012.07.002

Cohen, S., Levi-Montalcini, R., and Hamburger, V. (1954). Nerve growth-stimulating factor isolated from sarcomas 37 and 180. Proc. Natl. Acad. Sci. U.S.A. 40, 1014-1018. doi: 10.1073/pnas.40. 10.1014

Conrad, P. A., Meek, L. A., and Dumit, J. (2013). Operationalizing a one health approach to global health challenges. Comp. Immunol. Microbiol. Infect. Dis. 36, 211-216. doi: 10.1016/j.cimid.2013. 03.006
Cori, C. F., and Cori, G. T. (1925). The sugar concentration in arterial and venous blood during insulin action. Am. J. Physiol. 71, 688-707.

Cori, K. F., and Cori, G. T. (1923). A method for the study of liver metabolism. Proc. Soc. Exp. Biol. Med. 20, 409. doi: 10.3181/00379727-20-198

Dani, N., Barbosa, A. J., Del Rio, A., and Di Girolamo, M. (2013). ADP-ribosylated proteins as old and new drug targets for anticancer therapy: the example of ARF6. Curr. Pharm. Des. 19, 624-633. doi: 10.2174/138161213804581882

Dassati, S., Waldner, A., and Schweigreiter, R. (2014). Apolipoprotein D takes center stage in the stress response of the aging and degenerative brain. Neurobiol. Aging 35, 1632-1642. doi: 10.1016/j. neurobiolaging.2014.01.148

Deichmann, U., Schuster, S., Mazat, J. P., and Cornish-Bowden, A. (2014). Commemorating the 1913 Michaelis-Menten paper Die Kinetik der Invertinwirkung: three perspectives. FEBS J. 30, 121-123. doi: 10.1111/febs. 12598

Diederichs, S. (2014). The four dimensions of noncoding RNA conservation. Trends Genet. 281, 435-463. doi: 10.1016/j.tig.2014.01.004

Di Leva, G., and Croce, C. M. (2013). miRNA profiling of cancer. Curr. Opin. Genet. Dev. 23, 3-11. doi: 10.1016/j.gde.2013.01.004

Doll, C. A., and Broadie, K. (2014). Impaired activitydependent neural circuit assembly and refinement in autism spectrum disorder genetic models. Front. Cell Neurosci. 8:30. doi: 10.3389/fncel.2014. 00030

Dos Santos-Pinto, J. R., Lamprecht, G., Chen, W. Q., Heo, S., Hardy, J. G., Priewalder, H., et al. (2014). Structure and post-translational modifications of the web silk protein spidroin-1 from Nephila spiders. J. Proteomics. doi: 10.1016/j.jprot. 2014.01.002. [Epub ahead of print].

Embden, G., and Glaessner, K. (1901). About the place of the ether sulfuric acid formation in the animal body. [machine translation]. Beitr. z. chem. Physiol. u. Pathol. Pathol. 1, 310-327.

Falaleeva, M., and Stamm, S. (2013). Processing of snoRNAs as a new source of regulatory noncoding RNAs: snoRNA fragments form a new class of functional RNAs. Bioessays 35, 46-54. doi: 10.1002/bies.201200117

Fargin, A., Raymond, J. R., Lohse, M. J., Kobilka, B. K., Caron, M. G., and Lefkowitz, R. J. (1988). The genomic clone G-21 which resembles a $\beta$-adrenergic receptor sequence encodes the 5-HT1A receptor. Nature 335, 358-360. doi: 10.1038/335358a0

Fatica, A., and Bozzoni, I. (2014). Long non-coding RNAs: new players in cell differentiation and development. Nat. Rev. Genet. 15, 7-21. doi: $10.1038 / \mathrm{nrg} 3606$

Feng, X., Wang, Z., Fillmore, R., and Xi, Y. (2014). MiR-200, a new star miRNA in human cancer. Cancer Lett. 344, 166-173. doi: 10.1016/j.canlet. 2013.11.004

Fischer, E. H. (2013). Cellular regulation by protein phosphorylation. Biochem. Biophys. Res. Commun. 430, 865-867. doi: 10.1016/j.bbrc.2012. 10.024

Fischer, E. H., Graves, D. J., Crittenden, E. R. S., and Krebs, E. G. (1959). Structure of the site phosphorylated in the phosphorylase b to a reaction. J. Biol. Chem. 234, 1698-1704. 
Franklin, R. E. (1950). Influence of the bonding electrons on the scattering of X-rays by carbon. Nature 165, 71. doi: 10.1038/165071a0

Frielle, T., Collins, S., Daniel, K. W., Caron, M. G., Lefkowitz, R. J., and Kobilka, B. K. (1987). Cloning of the cDNA for the human $\beta 1$-adrenergic receptor. Proc. Natl. Acad. Sci. U.S.A. 84, 7920-7924. doi: 10.1073/pnas.84.22.7920

Galbete, C., Toledo, J., Martinez-Gonzalez, M. A., Martinez, J. A., Guillen-Grima, F., and Marti, A. (2013). Lifestyle factors modify obesity risk linked to PPARG2 and FTO variants in an elderly population: a cross-sectional analysis in the SUN Project. Genes Nutr. 8, 61-67. doi: 10.1007/s12263-0120296-4

Giulivi, C., Traaseth, N. J., and Davies, K. J. (2003). Tyrosine oxidation products: analysis and biological relevance. Amino Acids 25, 227-232. doi: 10.1007/s00726-003-0013-0

Gnankine, O., Bassole, I. H., Chandre, F., Glitho, I., Akogbeto, M., Dabire, R. K., et al. (2013). Insecticide resistance in Bemisia tabaci Gennadius (Homoptera: Aleyrodidae) and Anopheles gambiae Giles (Diptera: Culicidae) could compromise the sustainability of malaria vector control strategies in West Africa. Acta Trop. 128, 7-17. doi: 10.1016/j.actatropica.2013.06.004

Gonda, D. D., Akers, J. C., Kim, R., Kalkanis, S. N., Hochberg, F. H., Chen, C. C., et al. (2013). Neuro-oncologic applications of exosomes, microvesicles, and other nano-sized extracellular particles. Neurosurgery 72, 501-510. doi: 10.1227/NEU.0b013e3182846e63

Gould, N., Doulias, P. T., Tenopoulou, M., Raju, K., and Ischiropoulos, H. (2013). Regulation of protein function and signaling by reversible cysteine S-nitrosylation. J. Biol. Chem. 288, 26473-26479. doi: 10.1074/jbc.R113.460261

Gutierrez, A. H., Spero, D. M., Gay, C., Zimic, M., and De Groot, A. S. (2012). New vaccines needed for pathogens infecting animals and humans: one health. Hum. Vaccin. Immunother. 8, 971-978. doi: 10.4161/hv.20202

Hamaoka, T., McCully, K. K., Niwayama, M., and Chance, B. (2011). The use of muscle nearinfrared spectroscopy in sport, health and medical sciences: recent developments. Philos. Trans. A Math. Phys. Eng. Sci. 369, 4591-4604. doi: 10.1098/rsta.2011.0298

Harden, A. (1911). Alcoholic fermentation. London: Longmans, Green and Co.

Heim, R., Prasher, D. C., and Tsien, R. Y. (1994). Wavelength mutations and posttranslational autoxidation of green fluorescent protein. Proc. Natl. Acad. Sci. U. S. A. 91, 12501-12504. doi: 10. 1073/pnas.91.26.12501

Hershko, A., and Ciechanover, A. (1992). The ubiquitin system for protein degradation. Annu. Rev. Biochem. 61, 761-807. doi: 10.1146/annurev.bi.61. 070192.003553

Hershko, A., Ciechanover, A., Heller, H., Haas, A. L., and Rose, I. A. (1980). Proposed role of ATP in protein breakdown: conjugation of proteins with multiple chains of the polypeptide of ATPdependent proteolysis. Proc. Natl. Acad. Sci. U. S. A. 77, 1783-1786. doi: 10.1073/pnas.77.4.1783

Hill, A. C. (1898). LXVI.-Reversible zymohydrolysis. J. Chem. Soc. Trans. 73, 634-658. doi: $10.1039 /$ ct8987300634
Houssay, A. B. (1945). La accion diabetogena de la hipofisis. Buenos Aires: Sebastian de Amorrortu e Hijos.

Houssay, A. B. (1948). Diabetogenic activity of the fetal hypophysis. Rev. Soc. Argent. Biol. 24 24-27.

Inal, J. M., Kosgodage, U., Azam, S., Stratton, D., Antwi-Baffour, S., and Lange, S. (2013). Blood/plasma secretome and microvesicles. Biochim. Biophys. Acta 1834, 2317-2325. doi: 10. 1016/j.bbapap.2013.04.005

Jaenicke, L. (2007). Centenary of the award of a Nobel prize to Eduard Buchner, the father of biochemistry in a test tube and thus of experimental molecular bioscience. Angew. Chem. Int. Ed Engl. 46, 6776-6782. doi: 10.1002/anie.2007 00390

Johnson, J. A., Burkley, B. M., Langaee, T. Y., ClareSalzler, M. J., Klein, T. E., and Altman, R. B. (2012). Implementing personalized medicine: development of a cost-effective customized pharmacogenetics genotyping array. Clin. Pharmacol. Ther. 92, 437-439. doi: 10.1038/clpt.2012.125

Johnson, K. A. (2013). A century of enzyme kinetic analysis, 1913 to 2013. FEBS Lett. 587, 2753-2766. doi: 10.1016/j.febslet.2013.07.012

Johnsson, P., Lipovich, L., Grander, D., and Morris, K. V. (2014). Evolutionary conservation of long non-coding RNAs; sequence, structure, function. Biochim. Biophys. Acta 1840, 1063-1071. doi: 10.1016/j.bbagen.2013.10.035

Karplus, M. (1959). Contact electron-spin coupling of nuclear magnetic moments. J. Chem. Phys. 30, 11-15. doi: 10.1063/1.1729860

Karplus, M. (1963). Vicinal proton coupling in nuclear magnetic resonance. J. Am. Chem. Soc. 85, 2870-2871. doi: 10.1021/ja00901a059

Kim, T. H., Hwang, S. B., Jeong, P. Y., Lee, J., and Cho, J. W. (2005). Requirement of tyrosylprotein sulfotransferase-A for proper cuticle formation in the nematode C. elegans. FEBS Lett. 579, 53-58. doi: 10.1016/j.febslet.2004.11.044

Kornberg, A. (2003). Ten commandments of enzymology, amended. Trends Biochem. Sci. 28, 515-517. doi: 10.1016/j.tibs.2003.08.007

Kornberg, R. D. (1974). Chromatin structure: a repeating unit of histones and DNA. Science 184, 868-871. doi: 10.1126/science. 184.4139 .868

Kornberg, R. D. (1977). Structure of chromatin. Annu. Rev. Biochem. 46, 931-954. doi: 10.1146/annurev.bi.46.070177.004435

Krebs, H. A., and Johnson, W. A. (1937). Citric acid in intermediate metabolism in animal tissues. Enzymologia 4, 148-156.

Lee, T. H., D’Asti, E., Magnus, N., Al-Nedawi, K., Meehan, B., and Rak, J. (2011). Microvesicles as mediators of intercellular communication in cancer-the emerging science of cellular “debris." Semin. Immunopathol. 33, 455-467. doi: 10.1007/s00281-011-0250-3

Lee, Y., El Andaloussi, S., and Wood, M. J. (2012). Exosomes and microvesicles: extracellular vesicles for genetic information transfer and gene therapy. Hum. Mol. Genet. 21, R125-R134. doi: $10.1093 / \mathrm{hmg} / \mathrm{dds} 317$

Lehninger, A. L. (1942). The acid-splitting reaction of acetoacetic acid and the enzymic formation of acetic acid from acetoacetic acid. J. Biol. Chem. $143,147-157$.
Lehninger, A. L. (1945). Fatty acid oxidation and the Krebs trocarboxylic acid cycle. J. Biol. Chem. $161,413$.

Levi-Montalcini, R., and Amprino, R. (1947). Recherches experimentales sur l'origine du ganglion ciliaire dans l'embryon de poulet. Arch. Biol. (Liege). 58, 265-288.

Levitt, M., and Warshel, A. (1975). Computer simulation of protein folding. Nature (London) 253, 694-698. doi: 10.1038/253694a0

Louro, R., Smirnova, A. S., and Verjovski-Almeida, S. (2009). Long intronic noncoding RNA transcription: expression noise or expression choice? Genomics 93, 291-298. doi: 10.1016/j.ygeno.2008. 11.009

Lowe, B. (2009). Roman Iberia, Economy, Society and Culture. London: Duckworth.

Loyer, X., Vion, A. C., Tedgui, A., and Boulanger, C. M. (2014). Microvesicles as cell-cell messengers in cardiovascular diseases. Circ. Res. 114, 345-353. doi: 10.1161/CIRCRESAHA.113.300858

Lui, L., and Lowe, T. (2013). Small nucleolar RNAs and RNA-guided post-transcriptional modification. Essays Biochem. 54, 53-77. doi: 10.1042/bse0540053

Luo, Y., Guo, Z., and Li, L. (2013). Evolutionary conservation of microRNA regulatory programs in plant flower development. Dev. Biol. 380, 133-144. doi: 10.1016/j.ydbio.2013.05.009

Lyall, K., Schmidt, R. J., and Hertz-Picciotto, I. (2014). Maternal lifestyle and environmental risk factors for autism spectrum disorders. Int. J. Epidemiol. doi: 10.1093/ije/dyt282. [Epub ahead of print].

Maclean, L., Myburgh, E., Rodgers, J., and Price, H. P. (2013). Imaging African trypanosomes. Parasite Immunol. 35, 283-294. doi: 10.1111/pim. 12046

Manchester, K. L. (2000). Biochemistry comes of age: a century of endeavour. Endeavour 24, 22-27. doi: 10.1016/S0160-9327(99)01224-7

Marco, A., Ninova, M., and Griffiths-Jones, S. (2013). Multiple products from microRNA transcripts. Biochem. Soc. Trans. 41, 850-854. doi: 10.1042/BST20130035

Martens-Uzunova, E. S., Olvedy, M., and Jenster, G. (2013). Beyond microRNA-novel RNAs derived from small non-coding RNA and their implication in cancer. Cancer Lett. 340, 201-211. doi: 10.1016/j.canlet.2012.11.058

Martins, V. R., Dias, M. S., and Hainaut, P. (2013). Tumor-cell-derived microvesicles as carriers of molecular information in cancer. Curr. Opin. Oncol. 25, 66-75. doi: 10.1097/CCO.0b013e328 $35 \mathrm{~b} 7 \mathrm{c} 81$

Meyerhof, O. (1911). The Respiration of Sea Urchins Eggs (Strongylocentrotus lividus) in Pure Sodium Chloride Solutions. Biochem. Z. 33, 291-302.

Michaelis, L., and Menten, M. M. (2013). The kinetics of invertin action. 1913. FEBS Lett. 587, 2712-2720. doi: 10.1016/j.febslet.2013.07.015

Michelet, L., Zaffagnini, M., Morisse, S., Sparla, F., Perez-Perez, M. E., Francia, F., et al. (2013). Redox regulation of the Calvin-Benson cycle: something old, something new. Front. Plant Sci. 4:470. doi: 10.3389/fpls.2013.00470

Miller, M., and Olea-Popelka, F. (2013). One Health in the shrinking world: experiences with tuberculosis at the human-livestock-wildlife interface. Comp. Immunol. Microbiol. Infect. Dis. 36, 263-268. doi: 10.1016/j.cimid.2012.07.005 
Mitchell, P. (1961). Coupling of phosphorylation to electron and hydrogen transfer by a chemiosmotic type of mechanism. Nature 191, 144-148. doi: $10.1038 / 191144 \mathrm{a} 0$

Moeller, H. B., and Fenton, R. A. (2012). Cell biology of vasopressin-regulated aquaporin-2 trafficking. Pflugers Arch. 464, 133-144. doi: 10.1007/s00424012-1129-4

Moore, K. E., and Gozani, O. (2014). An unexpected journey: lysine methylation across the proteome. Biochim. Biophys. Acta. doi: 10.1016/j.bbagrm. 2014.02.008. [Epub ahead of print].

Mullis, K., Faloona, F., Scharf, S., Saiki, R., Horn, G., and Erlich, H. (1986). Specific enzymatic amplification of DNA in vitro: the polymerase chain reaction. Cold Spring Harb. Symp. Q. Biol. 51, 263-273. doi: 10.1101/SQB.1986.051.01.032

Nakagawa, S., and Kageyama, Y. (2014). Nuclear lncRNAs as epigenetic regulators-Beyond skepticism. Biochim. Biophys. Acta 1839, 215-222. doi: 10.1016/j.bbagrm.2013.10.009

Nandakumar, N., Buzney, S., and Weiter, J. J. (2012). Lipofuscin and the principles of fundus autofluorescence: a review. Semin. Ophthalmol. 27, 197-201. doi: 10.3109/08820538.2012.711415

Nandy, A., Gangopadhyay, S., and Mukhopadhyay, A. (2014). Individualizing breast cancer treatmentThe dawn of personalized medicine. Exp. Cell Res. 320, 1-11. doi: 10.1016/j.yexcr.2013.09.002

Napoli, E., Hung, C., Wong, S., and Giulivi, C. (2013). Toxicity of the flame-retardant BDE-49 on brain mitochondria and neuronal progenitor striatal cells enhanced by a PTEN-deficient background. Toxicol. Sci. 132, 196-210. doi: 10.1093/toxsci/kfs339

Nedic, O., Rattan, S. I., Grune, T., and Trougakos, I. P. (2013). Molecular effects of advanced glycation end products on cell signalling pathways, ageing and pathophysiology. Free Radic. Res. 47(Suppl. 1), 28-38. doi: 10.3109/10715762.2013.806798

Nie, Y., Erion, D. M., Yuan, Z., Dietrich, M., Shulman, G. I., Horvath, T. L., et al. (2009). STAT3 inhibition of gluconeogenesis is downregulated by SirT1. Nat. Cell Biol. 11, 492-500. doi: 10.1038/ncb1857

Nielsen, C. E., Wang, X., Robinson, R. J., Brooks, A. L., Lovaglio, J., Patton, K. M., et al. (2014). Carcinogenic and inflammatory effects of plutonium-nitrate retention in an exposed nuclear worker and beagle dogs. Int. J. Radiat. Biol. 90, 60-70. doi: 10.3109/09553002.2014.859765

Novelli, C. D., and Lipmann, F. (1947). The involvement of coenzyme A in acetate oxidation in yeast. J. Biol. Chem. 171, 833.

O'Carroll, D., and Schaefer, A. (2013). General principals of miRNA biogenesis and regulation in the brain. Neuropsychopharmacology 38, 39-54. doi: 10.1038/npp.2012.87

Ochoa, S., and Valdecasas, J. G. (1929). A microchemical method for the estimation of total creatinine in muscle. J. Biol. Chem. 81, 381-387.

Palotie, A., Widen, E., and Ripatti, S. (2013). From genetic discovery to future personalized health research. N. Biotechnol. 30, 291-295. doi: 10.1016/j.nbt.2012.11.013

Parnas, J. (1911). Fermentive acceleration by tissue juices of the cannizaro aldehyde transformation. $I$. Biochem. Z. 28, 274-294.

Pasteur, L. and Berthelot, M. (1906). Theory of fermentation. Compt. Rend. lxxxvii, 125-129.
Patel, K., Choy, S. S., Hicks, K. O., Melink, T. J., Holford, N. H., and Wilson, W. R. (2011). A combined pharmacokinetic model for the hypoxiatargeted prodrug PR-104A in humans, dogs, rats and mice predicts species differences in clearance and toxicity. Cancer Chemother. Pharmacol. 67, 1145-1155. doi: 10.1007/s00280-010-1412-z

Pauling, L., and Corey, R. B. (1951). Configurations of polypeptide chains with favored orientations around single bonds: two new pleated sheets. Proc. Natl. Acad. Sci. U.S.A. 37, 729-740. doi: 10.1073/pnas.37.11.729

Pauling, L., Corey, R. B., and Branson, H. R. (1951). The structure of proteins: two hydrogen-bonded helical configurations of the polypeptide chain. Proc. Natl. Acad. Sci. U.S.A. 37, 205-211. doi: 10.1073/pnas.37.4.205

Pauling, L., Itano, H. A., Singer, S. J., and Wells, I. C. (1949). Sickle cell anemia, a molecular disease. Science 110, 543-548. doi: 10.1126/science.110.2865.543

Perluigi, M., Swomley, A. M., and Butterfield, D. A. (2014). Redox proteomics and the dynamic molecular landscape of the aging brain. Ageing Res. Rev. 13C, 75-89. doi: 10.1016/j.arr.2013.12.005

Perutz, M. F. (1942). Crystal structure of oxyhemoglobin. Nature 150, 324-325. doi: $10.1038 / 150324 \mathrm{a} 0$

Pimentel, D., Haeussler, D. J., Matsui, R., Burgoyne, J. R., Cohen, R. A., and Bachschmid, M. M. (2012). Regulation of cell physiology and pathology by protein S-glutathionylation: lessons learned from the cardiovascular system. Antioxid. Redox Signal. 16, 524-542. doi: 10.1089/ars.2011.4336

Principe, S., Hui, A. B., Bruce, J., Sinha, A., Liu, F. F., and Kislinger, T. (2013). Tumorderived exosomes and microvesicles in head and neck cancer: implications for tumor biology and biomarker discovery. Proteomics 13, 1608-1623. doi: 10.1002/pmic.201200533

Quesenberry, P. J., and Aliotta, J. M. (2010). Cellular phenotype switching and microvesicles. Adv. Drug Deliv. Rev. 62, 1141-1148. doi: 10.1016/j.addr.2010.06.001

Rak, J. (2010). Microparticles in cancer. Semin. Thromb. Hemost. 36, 888-906. doi: 10.1055/s0030-1267043

Ramkumar, K. M., Sekar, T. V., Bhakkiyalakshmi, E., Foygel, K., Rajaguru, P., Berger, F., et al. (2013). The impact of oxidative stress on islet transplantation and monitoring the graft survival by non-invasive imaging. Curr. Med. Chem. 20, 1127-1146. doi: 10.2174/0929867311320090003

Razquin, C., Marti, A., and Martinez, J. A. (2011). Evidences on three relevant obesogenes: MC4R, FTO and PPARgamma. Approaches for personalized nutrition. Mol. Nutr. Food Res. 55, 136-149. doi: 10.1002/mnfr.201000445

Redman, C. W., Tannetta, D. S., Dragovic, R. A., Gardiner, C., Southcombe, J. H., Collett, G. P., et al. (2012). Review: does size matter? Placental debris and the pathophysiology of pre-eclampsia. Placenta 33(Suppl), S48-S54. doi: 10.1016/j.placenta.2011.12.006

Reid, I. R., Bolland, M. J., and Grey, A. (2014). Effects of vitamin D supplements on bone mineral density: a systematic review and meta-analysis. Lancet 383, 146-155. doi: 10.1016/S0140-6736(13) 61647-5
Running, M. P. (2014). The role of lipid post-translational modification in plant developmental processes. Front. Plant Sci. 5:50. doi: 10.3389/fpls.2014.00050

Russell, L. B. (2013). The Mouse House: a brief history of the ORNL mouse-genetics program, 1947-2009. Mutat. Res. 753, 69-90. doi: 10.1016/j.mrrev.2013. 08.003

Sadallah, S., Eken, C., and Schifferli, J. A. (2011). Ectosomes as modulators of inflammation and immunity. Clin. Exp. Immunol. 163, 26-32. doi: 10.1111/j.1365-2249.2010.04271.x

Sanger, F. (1945). Free amino groups of insulin. Biochem. J. 39, 507-515.

Schmidt, M., and Finley, D. (2014). Regulation of proteasome activity in health and disease. Biochim. Biophys. Acta 1843, 13-25. doi: 10.1016/j.bbamcr. 2013.08.012

Schmidt, R. J., Tancredi, D. J., Ozonoff, S., Hansen, R. L., Hartiala, J., Allayee, H., et al. (2012). Maternal periconceptional folic acid intake and risk of autism spectrum disorders and developmental delay in the CHARGE (CHildhood Autism Risks from Genetics and Environment) casecontrol study. Am. J. Clin. Nutr. 96, 80-89. doi: 10.3945/ajcn.110.004416

Schreiber, A., and Peter, M. (2014). Substrate recognition in selective autophagy and the ubiquitinproteasome system. Biochim. Biophys. Acta 1843 , 163-181. doi: 10.1016/j.bbamcr.2013.03.019

Shimomura, O. (1979). Structure of the chromophore of Aequorea green fluorescent protein. FEBS Lett. 104, 220-222. doi: 10.1016/0014-5793(79)80818-2

Sibley, D. R., Strasser, R. H., Benovic, J. L., Daniel, K., and Lefkowitz, R. J. (1986). Phosphorylation/dephosphorylation of the $\beta$-adrenergic receptor regulates its functional coupling to adenylate cyclase and subcellular distribution. Proc. Natl. Acad. Sci. U.S.A. 83, 9408-9412. doi: 10.1073/pnas.83.24.9408

Sidor, M. M., and McClung, C. A. (2014). Timing matters: using optogenetics to chronically manipulate neural circuitry and rhythms. Front. Behav. Neurosci. 8:41. doi: 10.3389/fnbeh.2014.00041

Smith, M. (1982). Site-directed mutagenesis. Trends Biochem. Sci. 7, 440-442. doi: 10.1016/S09680004(82)80013-3

Soleti, R., and Martinez, M. C. (2012). Sonic Hedgehog on microparticles and neovascularization. Vitam. Horm. 88, 395-438. doi: 10.1016/B978-0-12-394622-5.00018-3

Sousa Silva, M., Gomes, R. A., Ferreira, A. E., Ponces Freire, A., and Cordeiro, C. (2013). The glyoxalase pathway: the first hundred years... and beyond. Biochem. J. 453, 1-15. doi: 10.1042/BJ20121743

Spasser, L., and Brik, A. (2012). Chemistry and biology of the ubiquitin signal. Angew. Chem. Int. Ed. Engl. 51, 6840-6862. doi: 10.1002/anie.201200020

Springer, T., Galfre, G., Secher, D. S., and Milstein, C. (1979). Mac-1: a macrophage differentiation antigen identified by monoclonal antibody. Eur. J. Immunol. 9, 301-306. doi: 10.1002/eji.1830090410 Stenson, P. D., Mort, M., Ball, E. V., Shaw, K., Phillips, A., and Cooper, D. N. (2014). The Human Gene Mutation Database: building a comprehensive mutation repository for clinical and molecular genetics, diagnostic testing and personalized genomic medicine. Hum. Genet. 133, 1-9. doi: 10.1007/s00439-013-1358-4 
Storck, E. M., Serwa, R. A., and Tate, E. W. (2013). Chemical proteomics: a powerful tool for exploring protein lipidation. Biochem. Soc. Trans. 41, 56-61. doi: 10.1042/BST20120283

Tay, Y., Rinn, J., and Pandolfi, P. P. (2014). The multilayered complexity of ceRNA crosstalk and competition. Nature 505, 344-352. doi: 10.1038 /nature 12986

Tummler, K., Lubitz, T., Schelker, M., and Klipp, E. (2014). New types of experimental data shape the use of enzyme kinetics for dynamic network modeling. FEBS J. 281, 549-571. doi: 10.1111/febs. 12525

Ulmasov, B., Oshima, K., Rodriguez, M. G., Cox, R. D., and Neuschwander-Tetri, B. A. (2013). Differences in the degree of cerulein-induced chronic pancreatitis in C57BL/6 mouse substrains lead to new insights in identification of potential risk factors in the development of chronic pancreatitis. Am. J. Pathol. 183, 692-708. doi: 10.1016/j.ajpath.2013.05.020

van Dommelen, S. M., Vader, P., Lakhal, S., Kooijmans, S. A., van Solinge, W. W., Wood, M. J., et al. (2012). Microvesicles and exosomes: opportunities for cell-derived membrane vesicles in drug delivery. J. Control. Release 161, 635-644. doi: 10.1016/j.jconrel.2011.11.021

Vaudel, M., Sickmann, A., and Martens, L. (2014). Introduction to opportunities and pitfalls in functional mass spectrometry based proteomics. Biochim. Biophys. Acta 1844, 12-20. doi: 10.1016/j.bbapap.2013.06.019

Vernau, K. M., Runstadler, J. A., Brown, E. A., Cameron, J. M., Huson, H. J., Higgins, R. J., et al. (2013). Genome-wide association analysis identifies a mutation in the thiamine transporter 2 (SLC19A3) gene associated with Alaskan Husky encephalopathy. PLoS ONE 8:e57195. doi: 10.1371/journal.pone.0057195

Vickers, K. C., and Remaley, A. T. (2012). Lipidbased carriers of microRNAs and intercellular communication. Curr. Opin. Lipidol. 23, 91-97. doi: 10.1097/MOL.0b013e328350a425

Volk, S. W., and Theoret, C. (2013). Translating stem cell therapies: the role of companion animals in regenerative medicine. Wound Repair Regen. 21, 382-394. doi: 10.1111/wrr.12044

Walker, J. E., Saraste, M., Runswick, M. J., and Gay, N. J. (1982). Distantly related sequences in the alpha- and beta-subunits of ATP synthase, myosin, kinases and other ATP-requiring enzymes and a common nucleotide binding fold. EMBO J. 1, 945-951.

Wang, Y. C., Peterson, S. E., and Loring, J. F. (2014). Protein post-translational modifications and regulation of pluripotency in human stem cells. Cell Res. 24, 143-160. doi: 10.1038/cr.2013.151

Warshel, A., and Levitt, M. (1976). Theoretical studies of enzymic reactions: dielectric, electrostatic and steric stabilization of the carbonium ion in the reaction of lysozyme. J. Mol. Biol. 103, 227-249. doi: 10.1016/0022-2836(76)90311-9

Watson, J. D., and Crick, F. H. C. (1953). Genetical implications of the structure of deoxyribose nucleic acid. Nature 171, 964-967. doi: 10.1038/171964b0

Whitehead, J., Pandey, G. K., and Kanduri, C. (2009). Regulation of the mammalian epigenome by long noncoding RNAs. Biochim. Biophys. Acta 1790, 936-947. doi: 10.1016/j.bbagen.2008. 10.007

Williams, A. F., Galfre, G., and Milstein, C. (1977). Analysis of cell surfaces by xenogeneic myelomahybrid antibodies: differentiation antigens of rat lymphocytes. Cell 12, 663-673. doi: 10.1016/00928674(77)90266-5

Winter, G., Fersht, A. R., Wilkinson, A. J., Zoller, M., and Smith, M. (1982). Redesigning enzyme structure by site-directed mutagenesis: tyrosyl tRNA synthetase and ATP binding. Nature 299, 756-758. doi: 10.1038/299756a0

Yalow, R. S., Glick, S. M., Roth, J., and Berson, S. A. (1964). Radioimmunoassay of human plasma ACTH. J. Clin. Endocrinol. Metab. 24, 1219-1225. doi: 10.1210/jcem-24-11-1219

Yang, L., Vaitheesvaran, B., Hartil, K., Robinson, A. J., Hoopmann, M. R., Eng, J. K., et al. (2011). The fasted/fed mouse metabolic acetylome: N6-acetylation differences suggest acetylation coordinates organ-specific fuel switching. J. Proteome Res. 10, 4134-4149. doi: $10.1021 /$ pr200313x

Yang, X. J., and Chiang, C. M. (2013). Sumoylation in gene regulation, human disease, and therapeutic action. F1000Prime Rep. 5, 45. doi: 10.12703/ P5-45

Yoon, J. H., Abdelmohsen, K., and Gorospe, M. (2013). Posttranscriptional gene regulation by long noncoding RNA. J. Mol. Biol. 425, 3723-3730. doi: 10.1016/j.jmb.2012.11.024

Zaffagnini, M., Bedhomme, M., Lemaire, S. D., and Trost, P. (2012). The emerging roles of protein glutathionylation in chloroplasts. Plant Sci. 185-186, 86-96. doi: 10.1016/j.plantsci.2012.01.005

Zheng, W., Fu, S. X., Dydak, U., and Cowan, D. M. (2011). Biomarkers of manganese intoxication. Neurotoxicology 32, 1-8. doi: 10.1016/j.neuro. 2010.10.002

Zuckerkandl, E., and Pauling, L. (1962). "Molecular disease, evolution, and genetic heterogeneity," in Horizons in Biochemistry, eds M. Kasha and M. Pullman (New York, NY: Academic Press), 189-225.

Conflict of Interest Statement: The author declares that the research was conducted in the absence of any commercial or financial relationships that could be construed as a potential conflict of interest.

Received: 26 March 2014; accepted: 10 April 2014; published online: 29 April 2014.

Citation: Giulivi C (2014) Grand challenges in cellular biochemistry: the "next-gen" biochemistry. Front. Chem. 2:22. doi: 10.3389/fchem.2014.00022

This article was submitted to Cellular Biochemistry, a section of the journal Frontiers in Chemistry.

Copyright (c) 2014 Giulivi. This is an open-access article distributed under the terms of the Creative Commons Attribution License (CC BY). The use, distribution or reproduction in other forums is permitted, provided the original author(s) or licensor are credited and that the original publication in this journal is cited, in accordance with accepted academic practice. No use, distribution or reproduction is permitted which does not comply with these terms. 